\title{
Preliminary study of laminated, silt-rich debris bands: Matanuska Glacier, Alaska, U.S.A.
}

\author{
Stagi L. Ensminger, ${ }^{1}$ Edward B. Evenson, ${ }^{1}$ Grahame J. Larson, ${ }^{2}$ Daniel E. Lawson, ${ }^{3}$ \\ Righard B. Alley, ${ }^{4}$ Jeffrey C. Strasser, ${ }^{5}$ \\ ${ }^{1}$ Department of Earth and Environmental Sciences, Lehigh University, Bethlehem, PA 18015, U.S.A. \\ ${ }^{2}$ Department of Geological Sciences, Michigan State University, East Lansing, MI 61201, U.S.A. \\ ${ }^{3}$ U.S. Army Cold Regions Research and Engineering Laboratory, Anchorage, AK 99505, U.S.A. \\ ${ }^{4}$ Earth System Science Center and Department of Geosciences, The Pennsylvania State University, University Park, PA 16802, U.S.A. \\ ${ }^{5}$ Department of Geology, Augustana College, Rock Island, IL 61201, U.S.A.
}

\begin{abstract}
Several different types of laterally extensive debris bands occur along the western terminus region of the Matanuska Glacier, Alaska, U.S.A. An ice-bed process, which to our knowledge has not previously been recognized and described, forms the most common and most prominent type of debris band at Matanuska Glacier's terminus. The debris bands are composed of one or several millimeter-thick laminations of silt-rich ice having much higher sediment content than that of the surrounding ice. Samples of these bands and their surrounding englacial ice have been analyzed for anthropogenic tritium $\left({ }^{3} \mathrm{H}\right)$, oxygen-18 $\left(\delta^{18} \mathrm{O}\right)$, and deuterium $(\delta \mathrm{D})$. We interpreted the laminated, silt-rich debris bands as basal fractures, along which silt-laden, glaciohydraulically supercooled and pressurized waters flowed, healing the fractures by ice growth. This process is analogous to the inward growth of hydrothermal quartz from the sides of an open fracture.
\end{abstract}

\section{INTRODUGTION}

The objective of this study is to determine the origin of laminated, silt-rich debris bands found in the western terminus region of Matanuska Glacier, Alaska, U.S.A. Preliminary isotopic $\left({ }^{3} \mathrm{H}, \delta^{18} \mathrm{O}\right.$, and $\left.\delta \mathrm{D}\right)$ and sedimentological data are presented to assess mechanisms of formation. A new icebed process utilizing a pressurized and glaciohydraulically supercooled subglacial drainage system is proposed to explain the origins of these bands.

Several mechanisms have previously been proposed to explain debris band formation and its role in sediment transport. One is the "shear hypothesis" put forth by Goldthwait (1951). He hypothesized that "shear plane" transport could move debris from the base of the glacier along inclined planes to deposit subglacial material supraglacially (some as large as boulder-sized). Grove (1960) proposed that debris bands with a sediment load resembling coarse, angular supraglacial debris, form by the deposition of valley-wall materials on the ice surface in the accumulation area. These deposits are subsequently buried by snow that recrystallizes and is transported to the terminus, where the debris bands are exposed by ablation. A more recently proposed mechanism (Hubbard and Sharp, 1995) suggests that open crevasses fill with wind-blown or water-transported debris and subsequently close by ice flow. Clarke and Blake (1991) and Hambrey and others (1996) describe debris bands at a surge-type glacier that originate by thrusting during the surge, with the grain-size distribution containing a coarse, basally derived component.

The role of debris bands in sediment transport has been hypothesized to be important in the deposition of large land- forms associated with deglaciation events (Bishop, 1957; Moran, 1971; Stewart and MacClintock, 1971; Koteff, 1974; Sugden and John, 1976; Evenson and others, 1979; Ehlers, 1981; Koteff and Pessl, 1981; Mulholland, 1982). However, the importance of debris bands in sediment transport and deposition has also been discounted by several authors (Weertman, 1961; Boulton, 1970; Hooke, 1973; Evenson and Clinch, 1987; Gustavason and Boothroyd, 1987).

\section{SITE DESGRIPTION}

Matanuska Glacier is a $48 \mathrm{~km}$ long valley glacier that drains

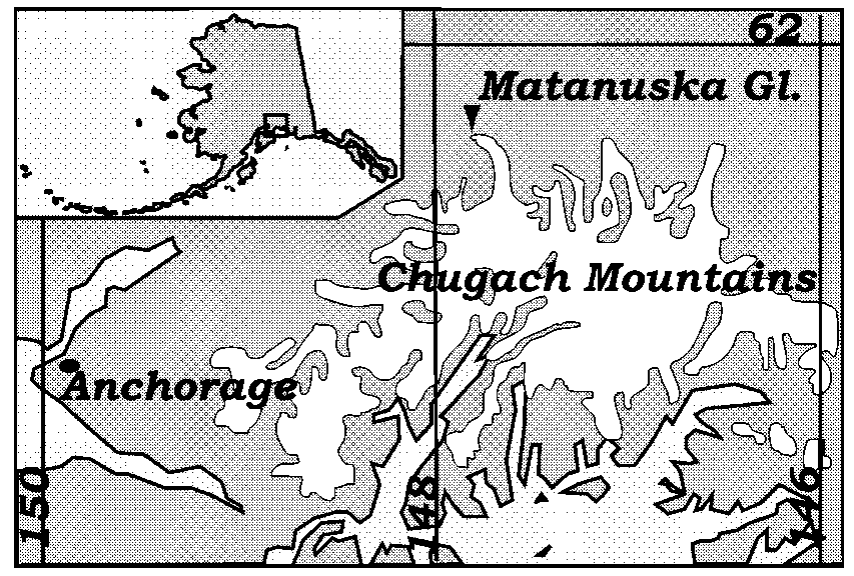

Fig. 1. Matanuska Glacier (approx. $60^{\circ} \mathcal{N}, 148^{\circ} \mathrm{W}$ ) flows north out of the Chugach Mountains and terminates in the upper Matanuska River Valley (arrow), $135 \mathrm{~km}$ northeast of Anchorage. 
$647 \mathrm{~km}^{2}$ of the Chugach Mountains in south-central Alaska (Williams and Ferrians, 1961) and flows north into the upper Matanuska River valley (Fig. 1). The terminus is $5 \mathrm{~km}$ wide and is located $135 \mathrm{~km}$ northeast of Anchorage. Elevation decreases from $3500 \mathrm{~m}$ a.s.l. in the accumulation zone to $559 \mathrm{~m}$ at the terminus. The southwestern portion of the terminus has been the focus of previous and current research on subglacial hydrology (e.g. Lawson, 1986, 1993; Ensminger and others, in press) and the growth and accretion of basal ice (Lawson and Kulla, 1978; Lawson, 1979a, b; Strasser and others, 1992; Lawson and others, 1996; Strasser and others, 1996; Alley and others, 1998; Lawson and others, 1998).

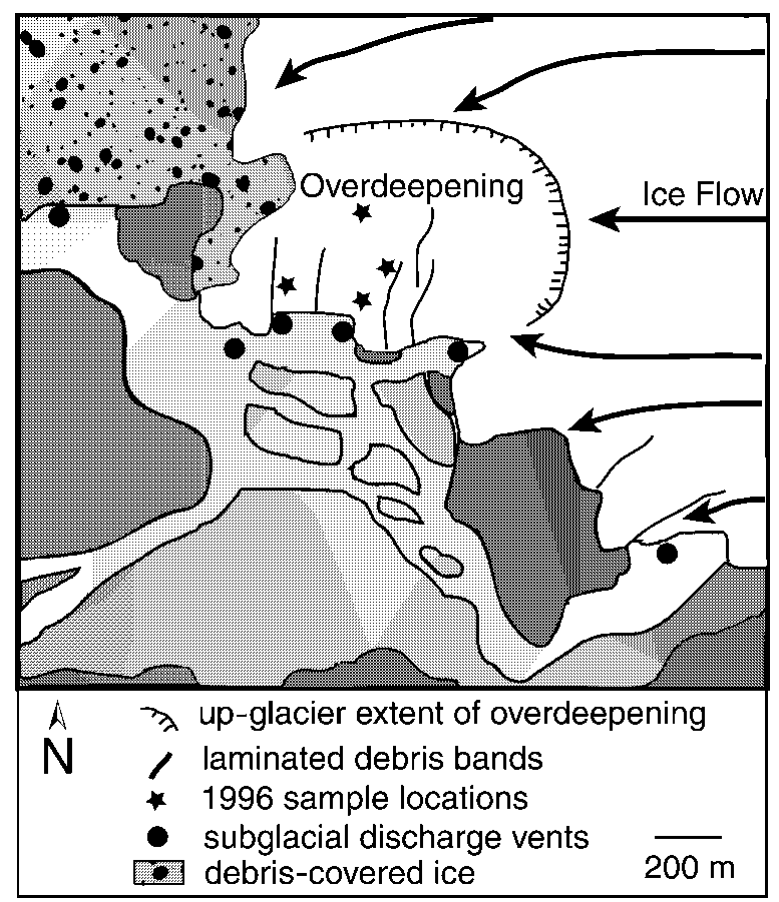

Fig. 2. Map traced from aerial photograph (1:10000) of southwestern region of Matanuska Glacier's terminus. Only a few debris bands are mappable at this scale. The adverse slopes responsible for glaciohydraulically supercooling the subglacial waters lie within the overdeepening. Laminated, siltrich debris bands are found only within or down-glacier of overdeepenings.

Ice flows out of several overdeepened basins along the western portion of Matanuska Glacier's terminus, as evidenced by the ice surface profile, crevasses, and ground-penetrating radar data (Arcone and others, 1995). The downglacier extent of one such overdeepening almost coincides with the current ice margin (Fig. 2). Supercooling can be caused by water flowing up the adverse slopes of such overdeepened basins, as the pressure-melting temperature can rise more rapidly than the water warms (Hooke and Pohjola, 1994; Lawson and others, 1996; Alley and others, 1998). Platy and dendritic frazil ice nucleates and grows in turbulent supercooled water (Forest, 1994), like that of Matanuska Glacier's subglacial discharge in overdeepened areas (Lawson and others, 1998). Terraces of frazil ice grow at the ice margin in conduit orifices and vents during the melt season (Strasser and others, 1996; Evenson and others, in press). Accretion of frazil ice to the base of the glacier is hypothesized to occur by processes similar to those known to produce ice terraces (Alley and others, 1998; Lawson and others, 1998).

Fracturing of the ice occurred at the ice margin within the overdeepening during recent melt seasons. The open fractures connected the ice surface to the drainage system. Some fractures contained small upwellings of sediment-laden water, suggesting a subglacial water source. Platy ice grew within this water as it discharged from the fractures, even during July when overnight air temperatures were above freezing. A drop in discharge subsequently exposed this new platy ice growth along the walls of one such fracture (Fig. 3).

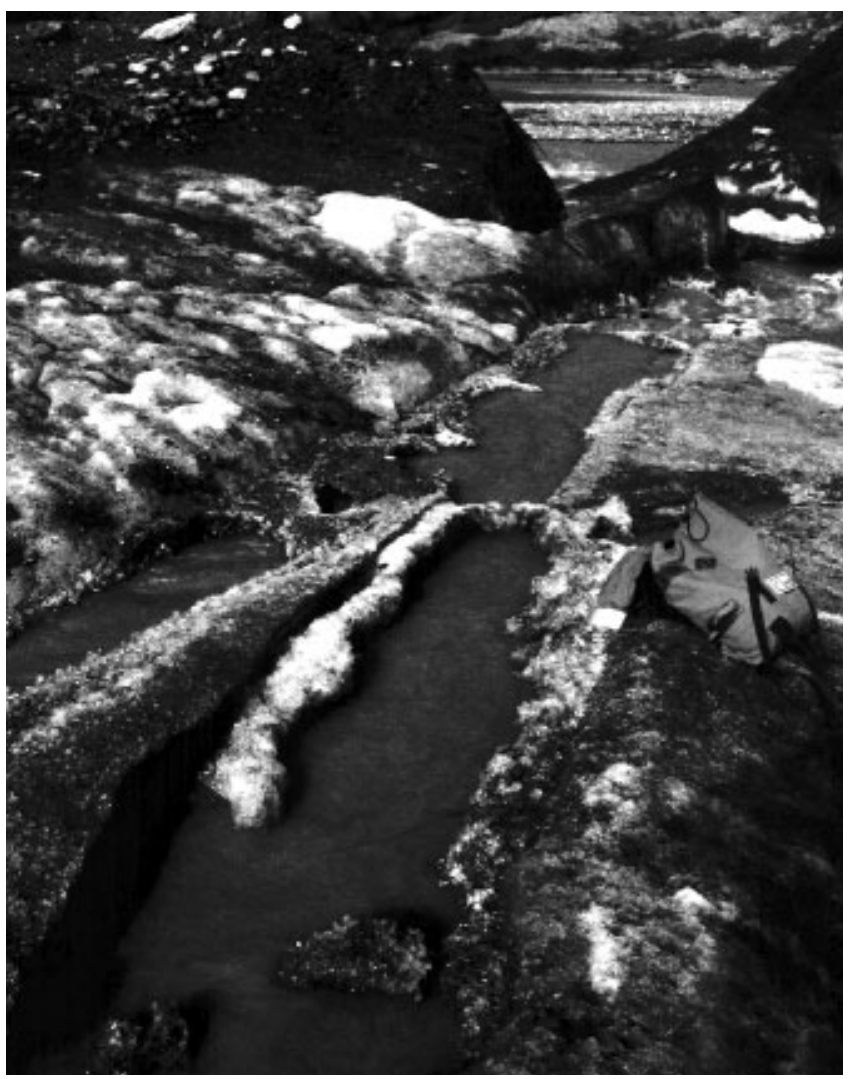

Fig. 3. Platy frazil-ice crystals grow subaqueously, inward from a newly opened fracture's walls. Frazil-ice growth occurs during periods of warm air temperature and high subglacial discharge. Ice crystals are exposed during periods of low discharge. A backpack is shown for scale.

\section{DEBRIS-BAND GHARACTER}

Laminated, sediment-rich debris bands are found within and down-glacier of overdeepened basins, near the ice margin where the subglacial drainage system is pressurized and supercooled. The debris bands are laterally extensive for hundreds of meters (Figs 2 and 4) and many trend in the same general southwest to northeast direction; however, other orientations are also observed. The debris bands usually have a steep to almost vertical up-glacier dip, but opposite dips do occur. Debris bands can often be traced laterally to where they contact one another, or a debris band may bifurcate in places along its length forming "lozenges" as it splits and rejoins (left of center, Fig. 4).

The sediment is visibly concentrated in a centrally located seam or in several subparallel laminations just a few millimeters thick. The sediment in laminated debris bands appears 


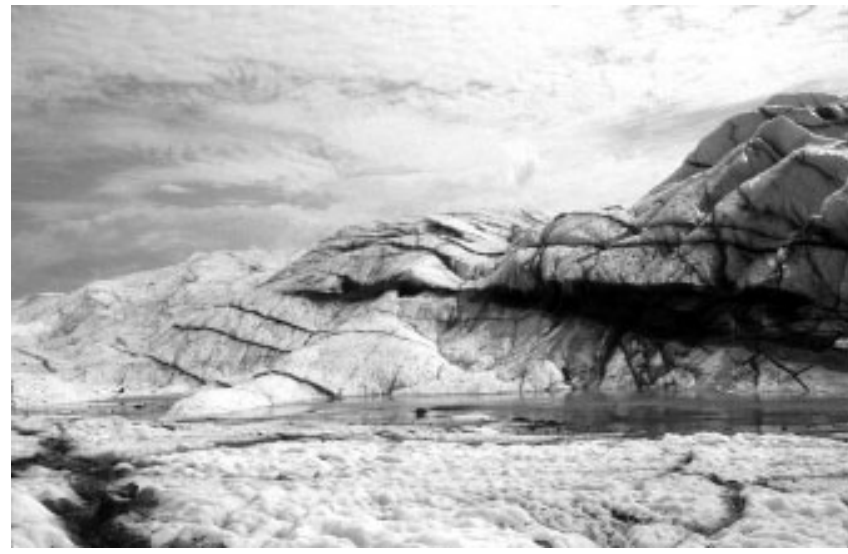

Fig. 4.View northeast to icefall near the margin. Several laminated, silt-rich debris bands lie approximately parallel to one another. The widest debris band (center) appears to be $1 \mathrm{~m}$ wide. Note there are three prominent "splays" branching off this debris band that also bifurcates in places along its length.

to consist predominantly of silt to very fine sand (Fig. 5a). Commonly, adjacent to the fine-grained debris laminations are subparallel clear, clean ice layers that are in contact with the bubbly, clean ice of the englacial zone (Fig. 5b). In some

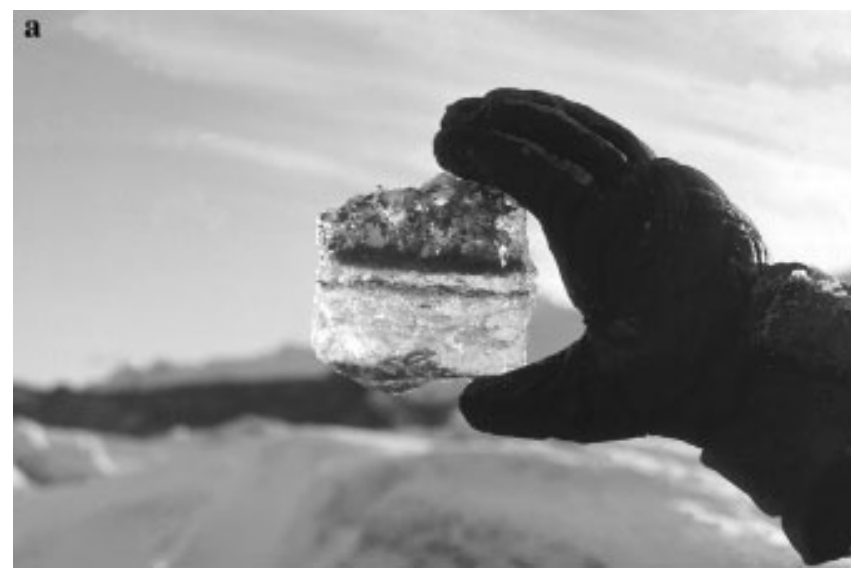

b

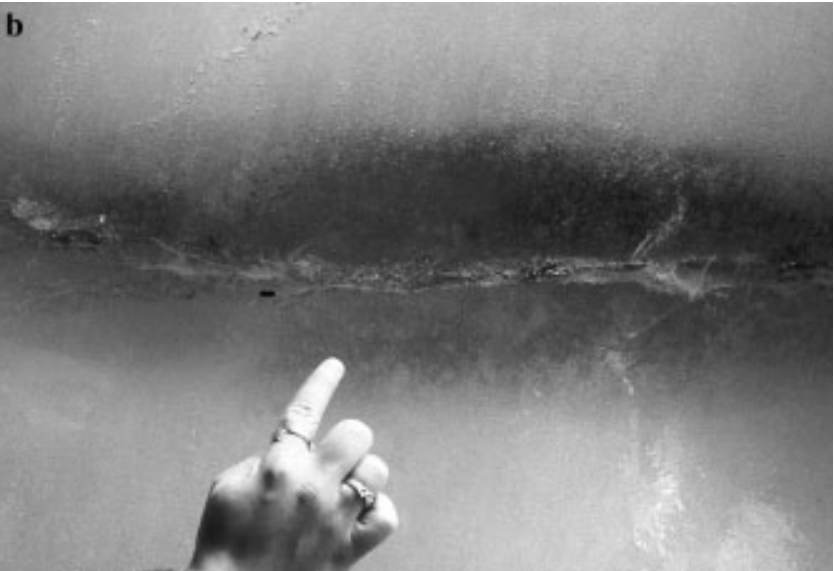

Fig. 5. (a) Hand specimen broken from the surface of a laminated, silt-rich debris band. Note the exceptionally clean ice lacking bubbles between the laminations. There is no observable coarse-fraction in the sediment. (b) Looking up at the roof of an ice cave. The centrally located seam of sediment has clean, clear diffused englacial ice, symmetric about either side. The white ice is clean, bubbly diffused facies ice of the englacial zone. (Hand for scale.) cases, debris bands can also be traced to a contact with the stratified basal ice (Lawson, 1979b; Hubbard and Sharp, 1995). Sediment released by ablation from the debris bands forms sediment flows on the ice surface (e.g. Lawson, 1982).

Open annuli or "conduits" can be found within laminated debris bands (Fig. 6). Conduits vary in diameter from a few centimeters to tens of centimeters. It is not uncommon for several conduits to be found near one another. Annular ice growth is characteristic inside these conduits. The conduits resemble the "fossil moulin" of Holmlund (1988) and the "crystal quirke" of Stenborg (1968) and, therefore, are possibly indicative of water-filled crevasse closure in polythermal ice. They may equally be indicative of supercooled water flow through fractures that subsequently close by inward ice growth.

\section{METHODS}

To test whether the ice of laminated, silt-rich debris bands is composed of "young" ice (post-1952) or "old" ice (pre-1952), samples of the debris bands and the surrounding ice were collected and tested for their ${ }^{3} \mathrm{H}$ content. ${ }^{3} \mathrm{H}$ concentrations in

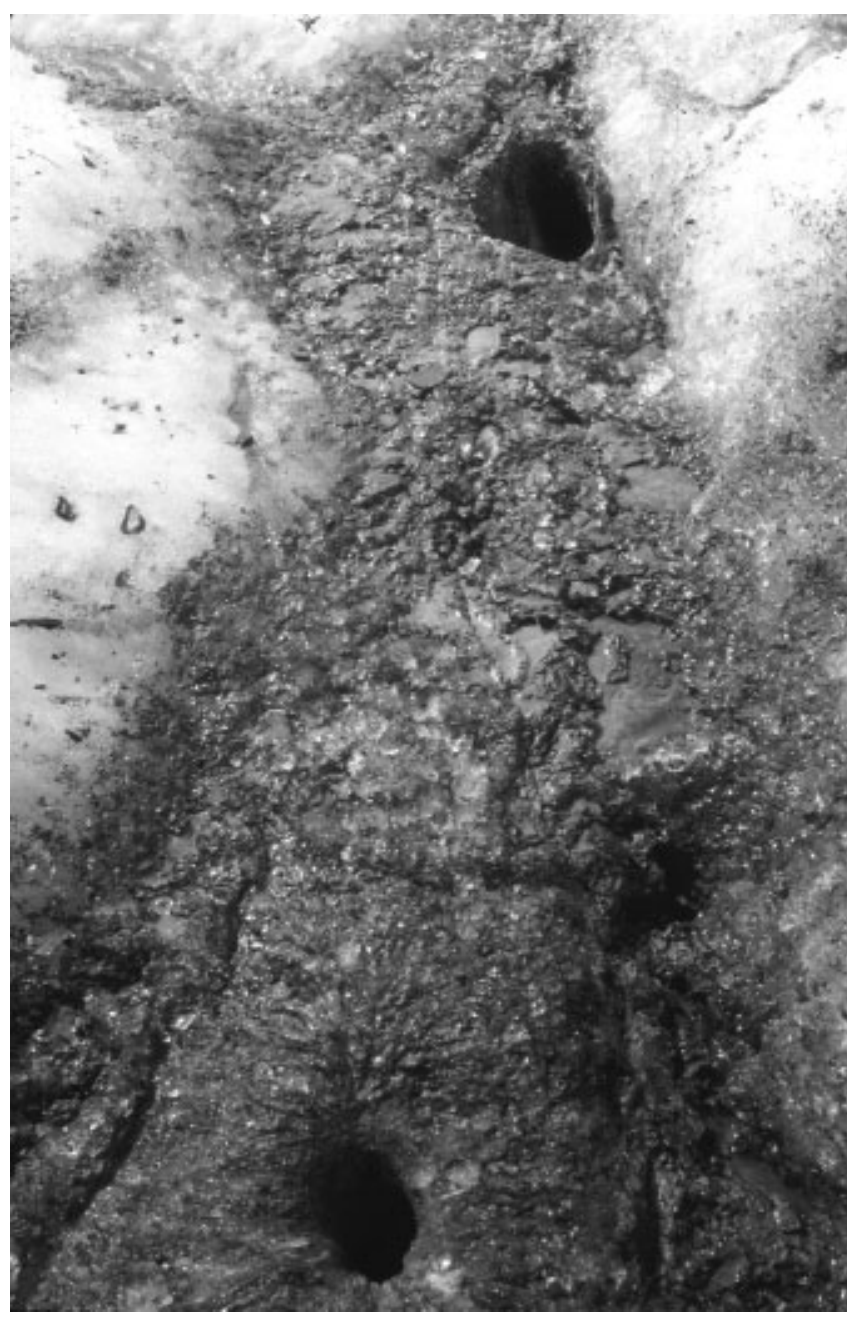

Fig. 6. Two adjacent open conduits in a debris band. The one near the top of the photograph is $0.1 \mathrm{~m}$ in diameter. Both conduits were open to a depth of approximately $2 \mathrm{~m}$ from the ice surface. The conduits may indicate crevasse closure in polythermal ice or flow of supercooled water into fractures with gradual closure by ice growth. 
precipitation were typically less than $25 \mathrm{TU}$ (where $1 \mathrm{TU}=$ $1{ }^{3} \mathrm{H}$ atom per $10^{181} \mathrm{H}$ atoms) prior to 1952 when thermonuclear bomb testing began. Testing released anthropogenic ${ }^{3} \mathrm{H}$ into the atmosphere (Libby, 1955; Gat, 1980) at thousands of TU above the background level (Leventhal and Libby, 1970). Because the estimated age of the englacial ice zone at Matanuska Glacier's terminus is greater than 150 years, snow from which it metamorphosed would contain background ${ }^{3} \mathrm{H}$ levels ( $<2$ TU; Strasser and others, 1996).

Ice frozen from post-1952 water should contain elevated ${ }^{3} \mathrm{H}$ concentrations. Water discharging from the subglacial conduits at the margin of the overdeepening contains ${ }^{3} \mathrm{H}$ approximately equal to that of precipitation today $(7-8 \mathrm{TU}$; Strasser and others, 1996). Ice of the stratified basal ice facies similarly contains higher quantities of ${ }^{3} \mathrm{H}$, but in varying amounts, and it is hypothesized that the ${ }^{3} \mathrm{H}$-rich ice originates by subglacial accretion (e.g. Strasser and others, 1996; Lawson and others, 1996, 1998).

If laminated debris bands are similarly formed, we anticipate ${ }^{3} \mathrm{H}$ concentrations similar to the stratified facies (6.3-17.5 TU; Strasser and others, 1996). Ice-surface velocities of approximately $70 \mathrm{~m} \mathrm{a}^{-1}$ have been measured within the ice-marginal overdeepening (Ensminger and others, in press). Based on these flow velocities and the distance from the ice margin to the up-glacier limit of the overdeepening, the ${ }^{3} \mathrm{H}$ values of any debris bands formed therein and up to about $3.4 \mathrm{~km}$ up-glacier of it should be similar to ${ }^{3} \mathrm{H}$ values of modern waters. The stable isotopes $\delta^{18} \mathrm{O}$ and $\delta \mathrm{D}$ are similarly anticipated to reflect modern meteoric and meltwater sources (e.g. Lawson and Kulla, 1978).

Samples for a preliminary study of ice composition were collected during late August, 1996. Four different laminated bands located within the overdeepening (star symbol, Fig. 2) near the ice margin were sampled, as well as the clean, bubbly englacial ice adjacent to those debris bands. The clean, clear diffused facies ice of the englacial zone (Lawson, 1979b) adjacent to one of the debris bands was also sampled. Another of the debris bands split in two near the top of an ice ridge and samples were collected from both limbs, as well as from the clean englacial ice in between. A total of five samples was collected from laminated debris bands, and 10 samples were collected from the diffused facies of the englacial zone, including the one sample from the clear englacial ice.

Ice samples were collected from nearly vertical faces located meters to tens of meters above the stratified basal ice. Samples were collected after the top few centimeters of ice were chipped away to remove any superimposed component (Lawson and Kulla, 1978). After melting, a volume of $30 \mathrm{~mL}$ was subsampled for stable isotope analysis and a volume of $60 \mathrm{~mL}$ was subsampled for unenriched ${ }^{3} \mathrm{H}$ analysis. Subsamples for debris content and sediment grain-size analyses were also collected. Sediment grain-size distributions were compared with those of different ice and water types described by Lawson (1979b).

Electrolytic enrichment and scintillation counting techniques (Kessler, 1988) were used to analyze samples for ${ }^{3} \mathrm{H}$ content at the low-level ${ }^{3} \mathrm{H}$ laboratory at Michigan State University. The analytical detection limit is $1 \mathrm{TU}$ with a precision of \pm 1 TU. Coastal Scientific Laboratories, Austin, Texas, analyzed the $\delta^{18} \mathrm{O}$ and $\delta \mathrm{D}$ samples with reported accuracies of $\pm 0.3 \%$ for $\delta^{18} \mathrm{O}$ and $\pm 5.0 \%$ o for $\delta \mathrm{D}$. The isotopic values of laminated debris bands were later compared to well-established englacial and basal ice values (cf. Lawson and Kulla, 1978; Strasser and others, 1996).

\section{RESULTS}

The laminated debris bands have elevated ${ }^{3} \mathrm{H}$ concentrations relative to those of the clean englacial ice. The average ${ }^{3} \mathrm{H}$ concentration is $6.6 \mathrm{TU}$ in the debris bands, whereas it is $<1 \mathrm{TU}$ in englacial ice (Table 1). $t$ tests yield $t=4.91$, and thus there is statistical evidence that the mean ${ }^{3} \mathrm{H}$ compositions represent different populations at the $99 \%$ significance level. Isotopic fractionation of ${ }^{3} \mathrm{H}$ during freezing is theoretically less than $4 \%$ and is therefore insignificant compared to natural variations of ${ }^{3} \mathrm{H}$ concentrations in precipitation or subglacial discharge (Strasser and others, 1996). ${ }^{3} \mathrm{H}$ data in this study have not been corrected to a reference date to account for the radioactive decay of ${ }^{3} \mathrm{H}\left(t_{1 / 2}=12.26\right.$ years $)$, but the uncorrected values still compare favorably to established values of the basal ice and subglacially discharged waters (Table 1; Strasser and others, 1996). These data suggest that the laminated debris bands are sourced by modern waters. The ${ }^{3} \mathrm{H}$ values of debris bands are less than half the recorded value of $26 \mathrm{TU}$ for ground water (Strasser and others, 1996; Lawson and others, 1998). This suggests debrisband construction is likely to occur during the melt season, rather than the winter when ground-water dominates the glacier's basal hydrologic system.

Table 1. Maximum, minimum, and average ${ }^{3} \mathrm{H}$ values (TU) of dirty ice from within laminated debris bands and their surrounding englacial ice compared to different ice and water types at Matanuska Glacier

\begin{tabular}{lcccc}
\hline Ice or water type & ${ }^{3} H_{\max T U}$ & ${ }^{3} H_{\min T U}$ & ${ }^{3} H_{\text {ave TU }}$ & ${ }^{3} H_{\text {std dev. TU }}$ \\
\hline Dirty debris-band ice & 9.6 & 4.3 & 6.6 & 2.4 \\
Englacial ice & 1.2 & -0.1 & 0.7 & 0.5 \\
Stratified basal ice ${ }^{1}$ & & & & \\
$\quad$ Profile 95-la & 91.5 & 13.3 & 38.5 & 18.6 \\
$\quad$ Profile 95-lc & 35.7 & -0.9 & 11.3 & 8.7 \\
Subglacial discharge $^{1}$ & 8.7 & 7.2 & 7.8 & 0.7 \\
Frazil and anchor ice $^{1}$ & 8.9 & 7.4 & 7.9 & 0.9 \\
& & & & \\
\hline
\end{tabular}

${ }^{1}$ Strasser and others (1996).

Stable isotope values of the laminated debris bands are similar to the heavier englacial ice values and lighter subglacial ice values (Table 2) reported by Lawson and Kulla (1978), Lawson and others (1998). Debris bands have $\delta^{18} \mathrm{O}$ values nearly identical to those of the subglacial discharge and frazil and anchor ice (Table 2) reported by Strasser and others (1996) and Lawson and others (1998).

Less negative $\delta^{18} \mathrm{O}$ values in the laminae than those of the englacial ice and the lack of air bubbles in debris-band ice would suggest a possible accretionary origin (Gow and others, 1979). However, the stable isotopes indicate that the ice of the laminated debris bands is forming within a closed water system. The $\delta \mathrm{D}$ values of debris bands are heavier than that of the subglacial discharge, but are nearly identical to values reported for frazil and anchor ice (Strasser and others, 1996). Two-tailed $t$ tests yield $t=1.12$ and 0.99 for $\delta^{18} \mathrm{O}$ and $\delta \mathrm{D}$, respectively. Stable-isotopic measurements on the debris-band ice do not differentiate it from englacial, basal, or frazil ice with high confidence, although possible differences suggest that further study will be valuable. 
Table 2. Maximum, minimum, and average stable-isotope values of dirty ice from within laminated debris bands and their surrounding englacial ice compared to different ice and water types at Matanuska Glacier

\begin{tabular}{|c|c|c|c|c|c|c|c|c|}
\hline Ice or water type & $\delta^{18} O_{-\max }$ & $\delta^{18} O_{\min }$ & $\delta^{18} O_{\text {ave }}$ & $\delta^{18} O_{\text {std dev. }}$ & $\delta D_{\max }$ & $\delta D_{\min }$ & $\delta D_{a v e}$ & $\delta D_{\text {std dev. }}$ \\
\hline Dirty debris-band ice & -21.8 & -24.5 & -23.1 & 1.3 & -165.0 & -178.0 & -172.8 & 6.0 \\
\hline Englacial ice & -21.8 & -25.8 & -23.9 & 1.3 & -159.0 & -189.0 & -177.5 & 10.5 \\
\hline Stratified basal ice ${ }^{1}$ & -19.6 & -23.3 & -21.0 & 0.6 & -149.0 & -178.0 & -163.8 & 4.7 \\
\hline Subglacial discharge $^{2}$ & -23.0 & -24.2 & -23.7 & 0.3 & -175.0 & -184.0 & -179.8 & 2.6 \\
\hline Frazil and anchor ice ${ }^{2}$ & -20.7 & -23.5 & -21.4 & 0.8 & -160.0 & -179.0 & -165.3 & 5.4 \\
\hline Precipitation $^{2}$ & -11.3 & -28.4 & -20.9 & 5.1 & -101.0 & -223.0 & -165.5 & 35.4 \\
\hline
\end{tabular}

${ }^{1}$ Strasser and others (1996).

2 Lawson and others (1998).

The average grain size of the sediment found within the debris band ice was $5 \phi$ (coarse silt) and well sorted $(\sigma=$ $1.54 \phi$, Fig. 7). This distribution closely resembles the average grain size of the suspended load of Matanuska Glacier's subglacial discharge (Lawson, 1993). The grain-size distribution of the dirty ice in laminated debris bands does not at all resemble the supraglacial debris described by Lawson (1979b). Therefore, we hypothesize that the debris consists of only the fine fraction of subglacial sediments like that which is incorporated into the stratified basal ice (Lawson, 1979b). Previously proposed mechanisms of debris-band genesis suggest that the debris component should resemble either supraglacial or basal debris, including its coarse fraction.

\section{DISGUSSION}

Analytical data and field observations at Matanuska Glacier require an alternative to existing theories of debris-band formation. We propose that basal fractures open with strongly extensional flow (such as over an icefall or within the deepest part of an overdeepening). As ice flows out of the overdeepened basin, high basal water pressure may force dirty subglacial water into the englacial zone along the fractures or crevasses (Weertman, 1973; Holmlund, 1988; Lawson and Hunter, 1996). Mickelson and Berkson (1974) described a

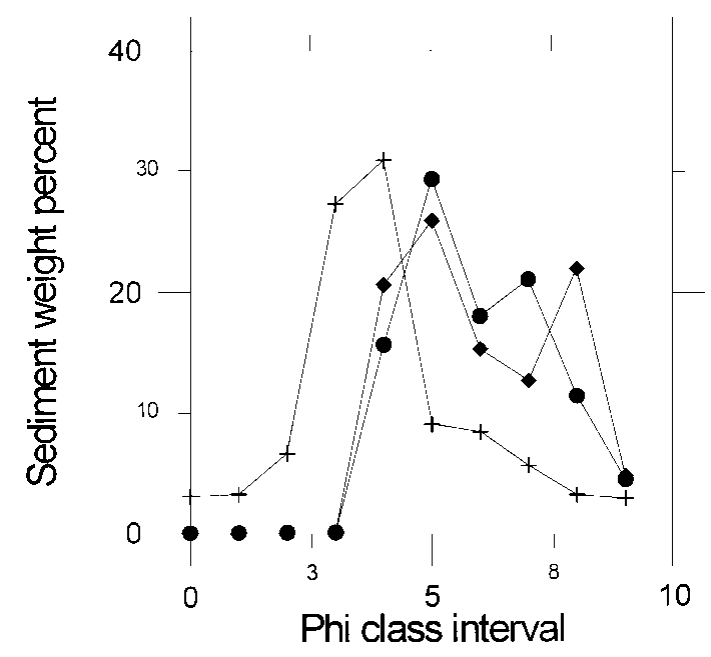

Coarse sand Coarse silt Fine silt

Fig. 7. Grain-size distribution of the dirty ice within laminated debris bands showing fine-grained and well-sorted sediments. somewhat similar ice-bed process as a mechanism of basaltill entrainment.

In a glaciohydraulically-supercooled area of the drainage system, like the western terminus region of Matanuska Glacier, frazil ice may nucleate on and grow inward from the crevasse walls. Healing occurs as the fracture closes, trapping and concentrating sediment within the otherwise clean englacial ice. Ablation of the ice surface exposes the debris bands as they may be formed in either blind or open fractures. Continued ice flow and deformation give the laminated debris bands a "shear-plane" appearance. Repeated opening and closing of a fracture may be the mechanism by which the laminations form. However, there is no direct evidence yet to support this hypothesis.

The preliminary results of ${ }^{3} \mathrm{H}$ levels and debris grain-size distribution support our hypothesis that the laminated, siltrich debris bands form by a previously undescribed ice-bed process. We have not observed any laminated debris bands that contain coarse-grained sediment. Based on measured ice surface flow velocities in one of the overdeepened basins, the debris bands within and down-glacier of the icefall should contain elevated levels of ${ }^{3} \mathrm{H}$, which they do. The stable isotope data do not irrefutably support the proposed glaciohydraulic origin. Additional, more detailed sampling is required to conclusively prove our hypothesis.

\section{GONGLUSIONS}

Existing theories of debris-band origins do not adequately explain the characteristics of the prominent, laminated debris bands in Matanuska Glacier's terminus region. Field observations have led us to formulate a new hypothesis of origin. We propose that this type of debris band forms in glaciohydraulically supercooled areas of a drainage system as the result of a previously undescribed ice-bed process involving basal fracturing or crevassing. As a preliminary test of our hypothesis, four laminated debris bands and their surrounding ice were analyzed in 1996 for their ${ }^{3} \mathrm{H}$ concentrations, $\delta^{18} \mathrm{O}$ and $\delta \mathrm{D}$ contents, and debris grain-size distributions. The results of our preliminary study generally support glaciohydraulic supercooling and ice growth in basal fractures as the origin for the laminated, silt-rich debris bands.

\section{AGKNOWLEDGEMENTS}

The authors wish to thank the Cold Regions Research and Engineering Laboratory and U.S. National Science Founda- 
tion (grant DACA89-95-K-0007) for financial support. We would like to thank B. Stevenson and K. Stevenson of Glacier Park Resort, Alaska for their logistical support, without whose help this project would not have been possible or such an enjoyable experience. Students of Lehigh University, Pennsylvania, Augustana College, Illinois and Glacier View High School, Alaska provided field assistance. We thank B. Hubbard and an anonymous reviewer whose comments improved this manuscript.

\section{REFERENCES}

Alley, R. B., D. E. Lawson, E. B. Evenson, J. C. Strasser and G. J. Larson 1998. Glaciohydraulic supercooling: a freeze-on mechanism to create stratified, debris-rich basal ice. II. Theory. 7. Glaciol., 44(148), 562-568.

Arcone, S. A., D. E. Lawson and A. J. Delaney. 1995. Short-pulse radar wavelet recovery and resolution of dielectric contrasts within englacial and basal ice of Matanuska Glacier, Alaska, U.S.A. F. Glaciol., 41 (137), 68-86.

Bishop, B. C. 1957. Shear moraines in the Thule area, northwest Greenland. SIPRE Res. Rep. 17.

Boulton, G. S. 1970. On the origin and transport of englacial debris in Svalbard glaciers. F. Glaciol., 9(56), 213-229.

Clarke, G. K. C. and E.W. Blake. 1991. Geometric and thermal evolution of a surge-type glacier in its quiescent state: Trapridge Glacier, Yukon Territory, Canada, 1969-89. F. Glaciol., 37(125), 158-169.

Ehlers, J. 1981. Some aspects of glacial erosion and deposition in north Germany. Ann. Glaciol., 2, 143-146.

Ensminger, S. L., E. B. Evenson, R. B. Alley, G. J. Larson, D. E. Lawson and J. C. Strasser. In press. Example of the dependence of ice motion on subglacial drainage system evolution: Matanuska Glacier, Alaska, U.S.A. In Mickelson, D. M. and J.V. Attig, eds. Glacial processes: past and present. Boulder, CO, Geological Society of America. (Special Paper 337.)

Evenson, E. B. and J. M. Clinch. 1987. Debris transport mechanisms at active alpine glacier margins: Alaska case studies. In Kujansuu, R. and M. Saarnisto, eds. INQUA Till Symposium, Finland 1985. Espoo, Geological Society of Finland, 111-136. (Geol. Surv. Finl. Spec. Pap. 3.)

Evenson, E. B., T. A. Pasquini, R. A. Stewart and G. Stephens. 1979. Systematic provenance investigations in areas of alpine glaciation: applications to glacial geology and mineral exploration. In Schlüchter, C., ed. Moraines and varves: origin/genesis/classification. Rotterdam, A.A. Balkema, 25-42.

Evenson, E. B., D. E. Lawson, J. C. Strasser, G. J. Larson, R. B. Alley and S. L. Ensminger. In press. Field evidence for the recognition of glaciohydraulic supercooling and basal ice accretion. In Mickelson, D. M. and J.V. Attig, eds. Glacial processes: past and present. Boulder, CO, Geological Society of America. (Special Paper 337.)

Forest, T. 1994. Physics of frazil ice. CRREL Spec. Rep. 94-23, 1-4.

Gat, J. R. 1980. The isotopes of hydrogen and oxygen in precipitation. In Fritz, P. and J. C. Fontes, eds. Handbook of environmental isotope geochemistry. Amsterdam, Elsevier, 21-47.

Goldthwait, R. P. 1951. Development of end moraines in east-central Baffin Island. 7. Geol., 59(6), 567-577.

Gow, A. J., S. Epstein and W. Sheehy. 1979. On the origin of stratified debris in ice cores from the bottom of the Antarctic ice sheet. F. Glaciol., 23(89), $185-192$

Grove, J. M. 1960. A study of Veslgjuv-breen. In Lewis, W.V., ed. Norwegian cirque glaciers. London, Royal Geographical Society, 69-82. (R.G.S. Research Series 4.)

Gustavson, T. C. and J. C. Boothroyd. 1987. A depositional model for outwash, sediment sources, and hydrologic characteristics, Malaspina Glacier, Alaska: a modern analog of the southeastern margin of the Laurentide ice sheet. Geol. Soc. Am. Bull., 99(2), 187-200.

Hambrey, M.J., J. A. Dowdeswell, T. Murray and P. R. Porter. 1996. Thrusting and debris entrainment in a surging glacier: Bakaninbreen, Svalbard. Ann. Glaciol., 22, 241-248.

Holmlund, P. 1988. Internal geometry and evolution of moulins, Storglaciären, Sweden. f. Glaciol., 34(117), 242-248.

Hooke, R. LeB. 1973. Structure and flow in the margin of the Barnes Ice
Cap, Baffin Island, N.W.T., Canada. 7. Glaciol., 12(66), 423-438.

Hooke, R. LeB. and V. A. Pohjola. 1994. Hydrology of a segment of a glacier situated in an overdeepening, Storglaciären, Sweden. f. Glaciol., 40 (134), 140-148.

Hubbard, B. and M. Sharp. 1995. Basal ice facies and their formation in the western Alps. Arct. Alp. Res., $27(4), 301-310$.

Kessler, M. J. 1988. Effective use of low level liquid scintillation analysis. In Proceedings, Second International Seminar for Liquid Scintillation Analysis, 8 Fune 1988, Tokyo, Japan, 256-301.

Koteff, C. 1974. The morphologic sequence concept and deglaciation of southern New England. In Coates, D. R., ed. Glacial geomorphology. Binghamton, NY, State University of New York, 121-144.

Koteff, C. and F. Pessl, Jr. 1981. Systematic ice retreat in New England. U.S. Geol. Surv. Prof. Pap. 1179.

Lawson, D. E. 1979a. Characteristics and origins of the debris and ice, Matanuska Glacier, Alaska. [Abstract.] 7. Glaciol., 23(89), 437-438.

Lawson, D. E. 1979b. A sedimentological analysis of the western terminus region of the Matanuska Glacier, Alaska. CRREL Rep. 79-9.

Lawson, D. E. 1982. Mobilization, movement and deposition of active subaerial sediment flows, Matanuska Glacier, Alaska. f. Geol., 90(3), 279-300.

Lawson, D. E. 1986. Observations on hydraulic and thermal conditions at the bed of Matanuska Glacier, Alaska. Eidg. Tech. Hochschule, Zürich. Versuchsanst. Wasserbau, Hydrol. Glaziol. Mitt., 90, 69-71.

Lawson, D. E. 1993. Glaciohydrologic and glaciohydraulic effects on runoff and sediment yield in glacierized basins. CRREL Monogr. 93-02.

Lawson, D. E. and L. E. Hunter. 1996. Glaciologic response to rapid fjord infilling during the marine to terrestrial transition, Muir Glacier, Glacier Bay, Alaska. [Abstract.] Geol. Soc. Am. Abstr. Programs, 28(7), 56.

Lawson, D. E. and J. B. Kulla. 1978. An oxygen isotope investigation of the origin of the basal zone of the Matanuska Glacier, Alaska. f. Geol., 86(6), 673-685.

Lawson, D. E., E. B. Evenson, J. C. Strasser, R. B. Alley and G. J. Larson. 1996. Subglacial supercooling, ice accretion, and sediment entrainment at the Matanuska Glacier, Alaska. [Abstract.] Geol. Soc. Am. Abstr. Programs, $28(3), 75$.

Lawson, D. E., J. C. Strasser, E. B. Evenson, R. B. Alley, G. J. Larson and S. A. Arcone. 1998. Glaciohydraulic supercooling: a freeze-on mechanism to create stratified, debris-rich basal ice. I. Field evidence. F. Glaciol., 44(148), 547-561.

Leventhal, J. S. and W. F. Libby. 1970. Tritium fallout in the Pacific United States. 7. Geophys. Res., 75 (36), 7628-7633.

Libby, W. F. 1955. Tritium in nature. F.Wash. Acad. Sci., 45(10), 301-314.

Mickelson, D. M. and J. M. Berkson. 1974. Till ridges presently forming above and below sea level in Wachusett Inlet, Glacier Bay, Alaska. Geogr. Ann., 56A (1-2), 111-119.

Moran, S. R. 1971. Glaciotectonic structures in drift. In Goldthwait, R. P., ed. Till: a symposium. Columbus, OH, Ohio State University Press, 127-148.

Mulholland, J.W. 1982. Glacial stagnation-zone retreat in New England: bedrock control. Geology, 10(11), 567-571.

Stenborg, T. 1968. Glacier drainage connected with ice structures. Geogr. Ann., 50A (1), 25-53.

Stewart, D. P. and P. MacClintock. 1971. Ablation till in northeastern Vermont. In Goldthwait, R. P., ed. Till: a symposium. Columbus, OH, Ohio State University Press, 106-114.

Strasser, E. B., D. E. Lawson, E. B. Evenson, J. C. Gosse and R. B. Alley. 1992. Frazil ice growth at the terminus of the Matanuska Glacier, Alaska, and its implications for sediment entrainment in glaciers and ice sheets. [Abstract.] Geol. Soc. Am. Abstr. Programs, 24(3), 78.

Strasser, J. C., D. E. Lawson, G. J. Larson, E. B. Evenson and R. B. Alley. 1996. Preliminary results of tritium analyses in basal ice, Matanuska Glacier, Alaska, U.S.A.: evidence for subglacial ice accretion. Ann. Glaciol., 22, 126-133.

Sugden, D. E. and B. S. John. 1976. Glaciers and landscape; a geomorphological approach. London, Edward Arnold.

Weertman, J. 1961. Mechanism for the formation of inner moraines found near the edge of cold ice caps and ice sheets. F. Glaciol., 3 (30), 965-978.

Weertman, J. 1973. Can a water-filled crevasse reach the bottom surface of a glacier? International Association of Scientific Hydrology Publication 95 (Symposium at Cambridge 1969 - Hydrology of Glaciers), 139-145.

Williams, J. R. and O.J. Ferrians, Jr. 1961. Late Wisconsin and recent history of the Matanuska Glacier, Alaska. Arctic, 14(2), 83-90. 